Egyptian Journal of Rabbit Science, 21 (1) 21-40(2011)

\title{
EFFECT OF REPLACEMENT OF BARLEY GRAINS AND SOYBEAN MEAL BY DISTILLER'S DRIED GRAINS WITH SOLUBLES WITH OR WITHOUT SUPPLEMENTED SEAWEED IN GROWING RABBIT RATIONS ON: 2. Calcium and phosphorus intake and absorption and some blood constituents of growing rabbits.
}

Tork M. I. Dorra*; H. M. E. Ead**; M. M. El-Shinnawy***; Eman H. M. Maklad**** and A. M. A. Sadek****.

* Department of Poultry Production, Faculty of Agriculture, Mansoura University, Egypt.

** Animal Production Research Institute, Agricultural Research Center, Dokki, Giza, Egypt.

*** Department of Animal Production, Faculty of Agriculture, Mansoura University, Egypt.

\section{ABSTRACT}

Twenty seven of weaning New Zealand White (NZW) rabbits of seven weeks of age was randomly distributed into nine groups of equal number (three rabbits in each) and similar average live body weight $(813 \mathrm{~g} \pm 0.01)$. Each group at 7, 9, 11 and 13 weeks of age was tended to determine $\mathrm{Ca}$, and $\mathrm{P}$ concentration in blood plasma. At 13 weeks old, blood samples were collected from the ear vein of the three rabbits in each group after overnight fasting during the last day of all growth trials. A representative part $(5 \mathrm{~cm})$ from the small intestine was dissected immediately after slaughtering of rabbits to determine $\mathrm{Ca}$ and $P$ absorption rates.

The experimental groups were fed randomly on one of the nine formulated experimental rations used. The $1^{\text {st }}$ ration (R1) was used as a control, which contained $10 \%$ yellow corn $+10 \%$ barley $+13.7 \%$ soybean meal $(S B M)+20 \%$ wheat bran $+40 \%$ clover hay $+3 \%$ molasses $+1 \%$ dicalcium phosphate $+1.2 \%$ limestone $+0.5 \%$ sodium chloride $+0.4 \%$ premix $+0.2 \%$ methionine and substituting the equal parts of barley and SBM by $10 \%$ and $20 \%$ distiller's dried grains with solubles (DDGS) for ration $2(R 2)$ and ration $3(R 3)$, respectively. The supplemented seaweed (SW) for these rations was at two levels. The first level was $0.5 \%$ seaweed of the total mixed ration for ration $4(R 4)$, ration 5 (R5) and ration 6 (R6). The second level was $1.0 \%$ seaweed of the total 
mixed ration for ration $7(R 7)$, ration $8(R 8)$ and ration $9(R 9)$. All rations were in pelleted form and nearly isonitrogenous and isocaloric.

The results of the present study revealed that $\mathrm{Ca}$ intake was increased $(P<0.05)$ with feeding DDGS on $R 8(1.92 \mathrm{~g} / \mathrm{h} / \mathrm{d})$ than the other rations, while feeding on $R 2, R 7$ and $R 9$ decreased $(P<0.05)$ Ca intake (1.67, 1.76 and $1.07 \mathrm{~g} / \mathrm{h} / \mathrm{d}$, respectively) at 12 to 13 weeks of age. Phosphorous intake was increased $(P<0.05)$ with feeding on R3, R5, R6 and $R 8(0.96,0.94,0.95$ and $0.96 \mathrm{~g} / \mathrm{h} / \mathrm{d}$, respectively). The mean values from 7 to 13 weeks old ranged from 0.61 to $0.71 \mathrm{~g} / \mathrm{h} / \mathrm{d}$ of the experimental rations. There was no significant effect with feeding on DDGS with or without SW on Ca and P absorption and concentration in blood plasma.

Urea- $N$ concentration in blood plasma was increased $(P<0.05)$ with feeding on $R 2, R 3$ and $R 7$ (45.95, 45.37 and $46.53 \mathrm{mg} / 100 \mathrm{ml}$, respectively) than the other ration groups.

The feeding $R 9$ was higher $(P<0.05)$ in cholesterol concentration $(224.68 \mathrm{mg} / 100 \mathrm{ml})$ than the other rations, while feeding on $R 3, R 5$ and $R 6$ were higher $(P<0.05)(202.22,213.84$ and $215.39 \mathrm{mg} / 100 \mathrm{ml}$, respectively) than the others. Triglycerides concentration was higher $(P<$ $0.05)$ with feeding $R 3, R 5, R 6, R 8$ and $R 9(107.26,122.02,115.62,119.56$ and $133.58 \mathrm{mg} / 100 \mathrm{ml}$, respectively) than the other rations, and total lipids was also higher with the same rations (430.0, 225.0, 267.5, 232.5 and $282.5 \mathrm{mg} / 100 \mathrm{ml}$, respectively). Low density lipoproteins (LDL) concentration was higher $(P<0.05)$ with feeding on $R 9$ (164.23 $\mathrm{mg} / 100 \mathrm{ml}$ ) than the other rations.

It could be concluded that feeding on DDGS without SW supplementation could be increased urea-N in blood plasma, triglycerides, cholesterol and total lipids in blood plasma of growing rabbits.

Keywords: Calcium, phosphorus, blood, growing rabbits, DDGS, SBM, seaweed.

\section{INTRODUCTION}

One of the more commonly held thoughts on calcium metabolism in rabbits is that the rabbit's gastrointestinal system is designed to absorb all the dietary calcium that is presented to it (Rosenthal, 2006). In other words, the more calcium in the food, the more calcium enters the gastrointestinal tract. Eventually, the theory goes, excess calcium in the body can not stay in the blood stream and is excreted though the urinary tract. This theory postulates that there is no delicate balancing act among calcium, phosphorous, vitamin $\mathrm{D}$ and parathyroid hormone 
(PTH) found in all other mammals. Without this ballet act among these four components, there is no gateway to prevent an overabundance of calcium absorption through the gastrointestinal tract. It is also thought that great majority of calcium absorbed by the gastrointestinal tract leaves the body through the urinary tract. This differs from almost all other mammals as studies and show in most animals other than rabbit's in which calcium is excreted, harmlessly through fecal material.

When calcium is measured in dietary experiments, it is important to look at the relationship of calcium to phosphorous. A limiting factor in the use of digestible $\mathrm{P}$ in diet formulations is accuracy of bioavailability estimates for feedstuffs (Robbins et. al., 2000). Therefore, in diets with higher energy contents, it may be necessary to raise the concentration of P. Ultimately, P requirements for market animals should probably be based on the amount of $P$ required per pound of lean tissue growth.

Monogastric animals do not secrete phytase in sufficient quantities to breakdown the phytate molecule; hence most of phytate $\mathrm{P}$ is not available for absorption (Soares and Jr., (1995). Therefore, large amounts of a highly available inorganic $P$ source must be added to meat the $P$ requirement. While most phytate $P$ is not available for absorption, much of this phytate $\mathrm{P}$ is mineralized to inorganic $\mathrm{P}$ in large intestine, and is excreted in manure as inorganic $\mathrm{P}$ and increase soluble $\mathrm{P}$ loss potential when applied to soils (Soares and Jr., (1995).

Rabbit rearing is an established micro livestock industry in many countries where rabbit are domesticated for meat. Broiler breeds of rabbits have also been introduced in India to explore its avenue as an alternative source of animal protein. Rabbit meat has high biological value (21\%) and low in fat and cholesterol (Sinha et.al., 2008).

There is a tradition of rabbit production in the five Mediterranean countries of Africa. Per caput production varies from Egypt's $0.27 \mathrm{Kg}$ to Morocco's nearly $0.78 \mathrm{Kg}$ (Lebas et. al., 1997).

Rabbits grow rapidly and its rate is comparable to that of broiler chicken (Sinha et.al., 2008). Proper nutrition is one of the important aspects of broiler rabbit production. The protein and energy content of the diet play a vital role in rabbit nutrition. Biochemical characterization of rabbit will help in better understanding of rabbit in relation to growth, meat, and fur quality.

By - product feed can serve as a source of nutrients in animal diets. Often, byproduct feed such as Distillers grains are included in the diet of they are readily available and economically justified, especially, when there is a shortage or increase in prices of conventional feed sources. Also, due the processing methods employed, nutrients in the by products become more biologically available and 
can potentially reduce nutrient excretion if the by product nutrient can be balanced in the diet (Spiehs et al., 2002).

Distiller's dried grains with soluble (DDGS) which contains from 0.62 to $0.87 \% \mathrm{P}$, have a higher concentration of available $\mathrm{P}$ than corn, other cereal grains and cereal co-products, averaging $77 \%$ for DDGS compared to a range of 12 to $30 \%$ for corn. Studies by Spiehs et al. (2002) showed that when formulating diets on a total $\mathrm{P}$ basis, the percentage of $\mathrm{P}$ retained tends to increase when 10 and $20 \%$ DDGS are added to growing diets compared to a control corn-soybean meal diets $(63.9 \%, 66.3 \%$ and $59.1 \%$, respectively).

Although the DDGS contains a significant amount of crude fiber $(8-10$ $\%$ ), it also contains $10-12 \%$ fat (Whitney et al., 1999). Fats as energy carriers and sources of essential unsaturated fatty acids have attracted the attention of nutritionists in recent years. The activity of these acids in the animal body is reflected mainly in the activity of eicosanoids (known as tissue hormones). Owing to the mechanism of their action, they can be treated as the most peripheral first messengers, which strengthen or weaken the regulatory activity of hormones and neuromediators at cellular level (Corl et al., 2003).

The chemical composition of ordinary seaweed as from Ascophyllum nodosum, immediately characterizes the material as of low-energy content. According to the analytical data the value of seaweed meal must primarily be sought in its content of vitamins and mineral among which $\beta$-carotene, tocopherols, some B vitamins, iodine, zinc and potassium are the more important components (Scott, 1990).

Mineral and vitamins are also of great importance in rabbit diets. It should be noted though that the rabbit cannot regulate its calcium absorption. Imbalances in calcium and phosphorous nutrition (too much $\mathrm{P}$ per unit $\mathrm{Ca}$ ) can lead to dental problems and urinary tract obstructions (Urolithiasis).

Therefore, the objective of this study was to evaluate the effect of partially or totally substituting of barley and partially of soybean meal by DDGS with or without seaweed supplementation on calcium and phosphorus absorption and some blood constituents of growing NZW rabbits and their effects on growth rate through $\mathrm{Ca}$ and $\mathrm{P}$ uptake and blood parameters.

\section{MATERIALS AND METHODS}

The experimental field of the present study was carried out at the Experimental Station of the Poultry Production Department, while, the chemical analysis was run at the Laboratory of the Animal Production Department, Faculty of Agriculture, Mansoura University, Mansoura, Egypt. 


\section{Experimental animals:}

Twenty seven of weaning New Zealand White (NZW) rabbits of seven weeks old was randomly distributed into nine groups of equal number (three rabbits in each) and similar average live body weight $(813 \mathrm{~g} \pm 0.01)$. All rabbits of each group at 7, 9, 11 and 13 weeks of age were tended to determined $\mathrm{Ca}$, and $\mathrm{P}$ concentration in blood plasma. At 13 weeks old, blood samples were collected from the ear vein of the rabbits in each group after overnight fasting during the last day of all growth trials.

\section{Treatments and experimental design:}

The experimental groups were fed randomly on one of the nine formulated experimental rations used. The experimental rations were designed to gradually substitute barley grains and soybean meal (equal parts) by distiller dried grains with solubles (DDGS) at the rate of 10 and $20 \%$ of the total mixed rations. Ration 1 (R1) contains $10 \%$ barley and $13.7 \%$ SBM as control diets, and the substituting the barley and SBM by $10 \%$ and $20 \%$ DDGS for ration 2 (R2) and ration 3 (R3), respectively. The supplemented seaweed for these rations was at two levels of the wheat bran. The first level was by $0.5 \%$ seaweed (SW) of the total mixed ration for ration 4 (R4), ration 5 (R5) and ration 6 (R6). The second level was by $1.0 \%$ seaweed of the total mixed ration for ration 7 (R7), ration 8 (R8) and ration 9 (R9). All rations were in pelleted form and nearly isonitrogenous and isocaloric content.

\section{Blood constituents' measurements.}

Blood samples were collected from the ear vein of the three rabbits in each group at 7, 9, 11 and 13 weeks old to determine $\mathrm{Ca}$, according to Moorhead and Briggs (1974) and P, according to Freidman et al.(1980). At 13 weeks old, blood samples were collected from the ear vein of rabbits in each group after overnight fasting during the last day of all growth trial. Blood plasma was separated after centrifugation at 4000 r.p.m. for 20 minutes, and then stored at $-20^{\circ} \mathrm{C}$ until analysis for the different blood parameters. Plasma was used for determination of total proteins, (Doumas et al.,1981); albumin, (Hill and Wells, 1983); globulin, which calculated by difference between the total proteins and albumin concentrations); AST and ALT, (Reitman and Frankel, 1957); alkaline phosphates, (Roy, 1970); urea-N, (Freidman et al., 1980); uric acid, (Fossati et al., 1980); creatinine (Fabiny and Ertingshausen, 1971); cholesterol(Allain et al., 1974); triglycerides (Fossati and Prencipe, 1982); total lipids (Zollner and Kirsch, 1962); HDL, (Lopes-Virella et al.,1977); LDL, (Friedewald et al., 1972), were carried out using photometric methods and diagnostic kits (Vitro Scient, Egypt), and $\mathrm{pH}$ determined by battery operated $\mathrm{pH}$ meter. 
Absorption of Ca and $P$ (in vitro) from intestine:

A representative part $(5 \mathrm{~cm})$ from the small intestine was dissected immediately after slaughtering of rabbits. The dissected tissues were immersed in $20 \mathrm{ml}$ of $\mathrm{CaHPO}_{4}$ solution in Petri dishes for one hour. After that the solution was collected in clean tubes and then used to determine $\mathrm{Ca}$ and $\mathrm{P}$ absorption rates. Absorption rates were calculated by subtracting the detected amounts in the collected samples from that in the immersed solutions. The methods of $\mathrm{Ca}$ and $\mathrm{P}$ determination were the same as those used for blood plasma samples by using available commercial kits.

\section{Statistical analysis:}

The statistical analysis was carried out using the General Linear Model Program (GLM) of SAS (2000). The obtained data were analyzed using factorial analysis $(3 \times 3)$ of variance according to the following model:

$$
Y_{i j k}=\mu+T_{i}+L_{j}+T_{i j}+e_{i j k}
$$

Where; Yijk $=$ Observation of the tested factor, $\mu=$ Overall mean, $\mathrm{Ti}=$ The effect of treatment (DDGS), $\mathrm{i}=0,10$ and $20 \%, \mathrm{Lj}=$ The effect of levels (seaweed), $\mathrm{j}=$ $0,0.5$ and $1 \%, \mathrm{TL}_{\mathrm{ij}}=$ The interaction between treatment and level effect and $\mathrm{e} \mathrm{ij}$ $\mathrm{k}=$ The random error associated with the individual ijk.

Differences among means were subjected to Duncan's Multiple Range Test (Duncan, 1955).

\section{RESULTS AND DISCUSSION}

\section{Effect of feeding with DDGS or SW supplementation and their interaction on Ca and $P$ intake:}

Table 1 shows that there was no significant effect of supplemented SW on $\mathrm{Ca}$ and $\mathrm{P}$ intake. The $\mathrm{Ca}$ and $\mathrm{P}$ intake increased with increasing the age from 7 to 13 weeks of age. These values of Ca intake were $(0.87,0.87$ and $0.90 \mathrm{~g} / \mathrm{h} / \mathrm{d})$ and $\mathrm{P}$ intake were $(0.44,0.43$ and $0.45 \mathrm{~g} / \mathrm{h} / \mathrm{d})$ at 7 to 8 weeks of age, while the values of Ca intake were $(1.79,1.84$ and $1.8 \mathrm{~g} / \mathrm{h} / \mathrm{d})$ and for $\mathrm{P}$ intake were $(0.09,0.92$ and $0.90 \mathrm{~g} / \mathrm{h} / \mathrm{d}$ ) at 12 to 13 weeks with supplemented $0.0,0.5$ and $1.0 \% \mathrm{SW}$, respectively. The mean values from 7 to 13 weeks for Ca intake were $(1.33,1.32$ and $1.34 \mathrm{~g} / \mathrm{h} / \mathrm{d}$ ) and for $\mathrm{P}$ intake were $(0.67,0.66$ and $0.67 \mathrm{~g} / \mathrm{h} / \mathrm{d})$ with supplemented $0.0 \%, 0.5 \%$ and $1.0 \% \mathrm{SW}$, respectively.

Data in Table 1 show that feeding on DDGS, data show that the Ca intake was increased $(\mathrm{P}<0.05)(1.78 \mathrm{~g} / \mathrm{h} / \mathrm{d})$ with feeding on $20 \%$ DDGS than the control $(1.57 \mathrm{~g} / \mathrm{h} / \mathrm{d})$, but there was no significant effect with feeding on $10 \%$ DDGS $(1.68$ $\mathrm{g} / \mathrm{h} / \mathrm{d}$ ) and control or with $20 \%$ DDGS at 11 to 12 week old. The mean values of 
Table 1. Main effects of SW supplementation or feeding DDGS on Ca and $P$ intake $(\mathrm{g} / \mathrm{h} / \mathrm{d})$ of growing rabbits.

\begin{tabular}{|c|c|c|c|c|c|c|c|c|c|c|}
\hline \multirow{2}{*}{ Items } & \multicolumn{5}{|c|}{ SW(\%) } & \multicolumn{5}{|c|}{ DDGS(\%) } \\
\hline & 0.0 & 0.5 & 1.0 & \pm SEM & $\boldsymbol{P}$ & 0.0 & 10.0 & 20.0 & \pm SEM & $\boldsymbol{P}$ \\
\hline \multicolumn{11}{|l|}{ Ca intake } \\
\hline $\mathrm{Wk}(7-8)$ & 0.87 & 0.87 & 0.90 & 0.013 & 0.130 & 0.87 & 0.89 & 0.88 & 0.013 & 0.517 \\
\hline Wk $(8-9)$ & 1.01 & 0.99 & 1.01 & 0.012 & 0.368 & 1.00 & 1.00 & 1.00 & 0.012 & 0.952 \\
\hline $\mathrm{Wk}(9-10)$ & 1.11 & 1.12 & 1.13 & 0.011 & 0.629 & 1.12 & 1.13 & 1.12 & 0.011 & 0.816 \\
\hline $\mathrm{Wk}(10-11)$ & 1.51 & 1.46 & 1.52 & 0.023 & 0.238 & 1.49 & 1.51 & 1.48 & 0.023 & 0.682 \\
\hline $\mathrm{Wk}(11-12)$ & 1.69 & 1.66 & 1.69 & 0.050 & 0.894 & $1.57^{\mathrm{b}}$ & $1.68^{\mathrm{ab}}$ & $1.78^{\mathrm{a}}$ & 0.050 & 0.031 \\
\hline $\mathrm{Wk}(12-13)$ & 1.79 & 1.84 & 1.80 & 0.034 & 0.562 & 1.81 & 1.82 & 1.80 & 0.034 & 0.837 \\
\hline Mean & 1.33 & 1.32 & 1.34 & 0.013 & 0.630 & 1.31 & 1.34 & 1.34 & 0.013 & 0.155 \\
\hline \multicolumn{11}{|l|}{ P intake } \\
\hline $\mathrm{Wk}(7-8)$ & 0.44 & 0.43 & 0.45 & 0.007 & 0.138 & $0.42^{\mathrm{b}}$ & $0.44^{\mathrm{a}}$ & $0.46^{\mathrm{a}}$ & 0.007 & 0.001 \\
\hline $\mathrm{Wk}(8-9)$ & 0.50 & 0.49 & 0.51 & 0.006 & 0.387 & $0.48^{c}$ & $0.50^{\mathrm{b}}$ & $0.52^{\mathrm{a}}$ & 0.006 & 0.001 \\
\hline $\mathrm{Wk}(9-10)$ & 0.56 & 0.56 & 0.56 & 0.006 & 0.658 & $0.54^{\mathrm{b}}$ & $0.56^{\mathrm{a}}$ & $0.58^{\mathrm{a}}$ & 0.006 & 0.0003 \\
\hline $\mathrm{Wk}(10-11)$ & 0.75 & 0.73 & 0.76 & 0.012 & 0.276 & $0.72^{b}$ & $0.76^{\mathrm{a}}$ & $0.77^{\mathrm{a}}$ & 0.012 & 0.012 \\
\hline $\mathrm{Wk}(11-12)$ & 0.85 & 0.83 & 0.84 & 0.025 & 0.905 & $0.76^{\mathrm{c}}$ & $0.84^{\mathrm{b}}$ & $0.93^{\mathrm{a}}$ & 0.025 & 0.001 \\
\hline $\mathrm{Wk}(12-13)$ & 0.90 & 0.92 & 0.90 & 0.017 & 0.569 & $0.87^{b}$ & $0.91^{\mathrm{ab}}$ & $0.93^{\mathrm{a}}$ & 0.017 & 0.046 \\
\hline Mean & 0.67 & 0.66 & 0.67 & 0.006 & 0.655 & $0.63^{c}$ & $0.67^{b}$ & $0.70^{a}$ & 0.006 & $<.0001$ \\
\hline
\end{tabular}

Ca intake were (1.31, 1.34 and $1.34 \mathrm{~g} / \mathrm{h} / \mathrm{d})$ with feeding on $0.0 \%, 10 \%$ and $20 \%$ DDGS, respectively. Phosphorous intake was increased $(\mathrm{P}<0.05)$ with feeding on 10 or $20 \%$ DDGS. The values for P intake were $(0.42,0.44$ and $0.46 \mathrm{~g} / \mathrm{h} / \mathrm{d})$ at 7 to 8 week and $(0.87,0.91$ and $0.93 \mathrm{~g} / \mathrm{h} / \mathrm{d})$ at 12 to 13 week, while the mean values were $(0.63,0.67$ and $0.70 \mathrm{~g} / \mathrm{h} / \mathrm{d})$ for 7 to 13 weeks with feeding on $0.0 \%, 10 \%$ and $20 \%$ DDGS, respectively.

Obtained results as shown in Table 2, present the interaction effect of feeding on DDGS with or without $\mathrm{SW}$, show that the Ca intake was increased $(\mathrm{P}<$ $0.05)$ with feeding on $\mathrm{R} 8(1.92 \mathrm{~g} / \mathrm{h} / \mathrm{d})$ than the other rations, while feeding on $\mathrm{R} 2$, R7 and R9 were decreased $(\mathrm{P}<0.05) \mathrm{Ca}$ intake $(1.67,1.76$ and $1.07 \mathrm{~g} / \mathrm{h} / \mathrm{d}$, respectively) at 12 to 13 weeks old. The mean values from 7 to 13 weeks of age were ranged from 1.27 to $1.37 \mathrm{~g} / \mathrm{h} / \mathrm{d}$. Phosphorous intake increased $(\mathrm{P}<0.05)$ with feeding on R3, R5, R6 and R8 (0.96, 0.94, 0.95 and $0.96 \mathrm{~g} / \mathrm{h} / \mathrm{d}$, respectively). The mean values of 7 to 13 weeks old ranged from $(0.61$ to $0.71 \mathrm{~g} / \mathrm{h} / \mathrm{d})$. 
Table 2. Interaction effects between feeding on DDGS and with or without $S W$ on $\mathrm{Ca}$ and $\mathrm{P}$ intake $(\mathrm{g} / \mathrm{h} / \mathrm{d})$ of growing rabbits.

\begin{tabular}{|c|c|c|c|c|c|c|c|c|c|c|c|}
\hline Items & $\mathbf{R} 1$ & $\mathbf{R 2}$ & $\mathbf{R 3}$ & $\mathbf{R 4}$ & R5 & R6 & $\mathbf{R 7}$ & R8 & R9 & & \\
\hline DDGS(\%) & 0.0 & 10.0 & 20.0 & 0.0 & 10.0 & 20.0 & 0.0 & 10.0 & 20.0 & \pm SEM & $\boldsymbol{P}$ \\
\hline SW(\%) & & 0.0 & & & 0.5 & & & 1.0 & & & \\
\hline \multicolumn{12}{|c|}{ Ca intake $(g / h / d):$} \\
\hline Wk $(7-8)$ & 0.87 & 0.89 & 0.86 & 0.84 & 0.88 & 0.88 & 0.90 & 0.89 & 0.92 & 0.023 & 0.659 \\
\hline Wk $(8-9)$ & 0.99 & 1.02 & 1.00 & 0.98 & 0.99 & 1.01 & 1.03 & 1.00 & 1.00 & 021 & .471 \\
\hline Wk $(9-10)$ & 1.12 & 1.11 & 1.11 & 1.11 & 1.13 & 1.12 & 1.13 & 1.14 & 1.12 & 0.020 & 0.831 \\
\hline Wk $(10-11)$ & 1.55 & 1.52 & 1.46 & 1.40 & 1.49 & 1.49 & 1.52 & 1.52 & 1.51 & 0.041 & 0.313 \\
\hline Wk $(11-12)$ & 1.60 & 1.61 & 1.86 & 1.49 & 1.68 & 1.81 & 1.63 & 1.75 & 1.68 & 0.087 & 0.334 \\
\hline Wk $(12-13)$ & 1.85 & 1.67 & 1.86 & 1.81 & 1.88 & 1.83 & 1.76 & 1.92 & 1.70 & 0.059 & 0.027 \\
\hline Mean & 1.33 & 1.30 & 1.36 & 1.27 & 1.34 & 1.35 & 1.33 & 1.37 & 1.32 & 0.022 & 0.083 \\
\hline \multicolumn{12}{|c|}{ P intake $(g / h / d):$} \\
\hline Wk $(7-8)$ & 0.42 & 0.45 & 0.45 & 0.40 & 0.44 & 0.46 & 0.43 & 0.45 & 0.48 & 0.011 & 0.668 \\
\hline Wk $(8-9)$ & 0.48 & 0.51 & 0.52 & 0.47 & 0.49 & 0.52 & 0.50 & 0.50 & 0.52 & 0.010 & 0.515 \\
\hline Wk $(9-10)$ & 0.54 & 0.55 & 0.58 & 0.53 & 0.57 & 0.58 & 0.54 & 0.57 & 0.58 & 0.010 & 0.852 \\
\hline Wk $(10-11)$ & 0.74 & 0.76 & 0.76 & 0.67 & 0.75 & 0.77 & 0.73 & 0.76 & 0.78 & 0.021 & 0.361 \\
\hline Wk $(11-12)$ & 0.77 & 0.80 & 0.97 & 0.71 & 0.84 & 0.94 & 0.78 & 0.87 & 0.87 & 0.043 & 0.320 \\
\hline Wk $(12-13)$ & 0.89 & 0.84 & 0.96 & 0.87 & 0.94 & 0.95 & 0.85 & 0.96 & 0.88 & 0.030 & 0.028 \\
\hline Mean & 0.64 & 0.65 & 0.71 & 0.61 & 0.67 & $\mathbf{0 . 7 0}$ & 0.64 & 0.69 & 0.69 & 0.011 & 0.080 \\
\hline
\end{tabular}

The present results were in agreement with those of authors who reported that growing rabbits should be fed to appetite until 10 weeks of age and then at around $112 \mathrm{~g} \mathrm{DM} /$ day (Santoma et al., 1989). The Ca and $\mathrm{P}$ requirements of growing rabbits are 1.15 and $0.6 \%$, respectively (Moughan et al., 1988). Where, the $\mathrm{Ca}$ and $\mathrm{P}$ intake of growing rabbits were $(1.30$ and $0.67 \mathrm{~g} / \mathrm{h} / \mathrm{d}$, respectively).

Effect of $S W$ supplementation or feeding DDGS and their interaction on Ca (mol/hr) and P (mol/hr) absorption:

Table (3) shows the absorption rate of $\mathrm{Ca}$ and $\mathrm{P}$ at 13 weeks of age. The results showed that there were no significant effect of with SW or

Table 3. Main effects of SW supplementation or feeding DDGS on Ca $(\mathrm{mol} / \mathrm{hr})$ and $P(\mathrm{~mol} / \mathrm{hr})$ absorption at week 13 of age.

\begin{tabular}{|c|c|c|c|c|c|c|c|c|c|c|}
\hline \multirow{2}{*}{ Items } & \multicolumn{5}{|c|}{ SW(\%) } & \multicolumn{5}{|c|}{ DDGS(\%) } \\
\hline & 0.0 & 0.5 & 1.0 & \pm SEM & $P$ & 0.0 & 10.0 & 20.0 & \pm SEM & $P$ \\
\hline $\mathrm{Ca}(\mathrm{mol} / \mathrm{hr})$ & 2.71 & 2.65 & 2.76 & 0.124 & 0.821 & 2.72 & 2.73 & 2.68 & 0.124 & 0.960 \\
\hline $\mathbf{P}(\mathrm{mol} / \mathrm{hr})$ & 1.12 & 1.15 & 1.12 & 0.059 & 0.917 & 1.16 & 1.10 & 1.13 & 0.059 & 0.827 \\
\hline
\end{tabular}


feeding on DDGS on $\mathrm{Ca}$ and $\mathrm{P}$ absorption. the mean values for $\mathrm{Ca}$ absorption ranged from 2.65 to $2.76(\mathrm{~mol} / \mathrm{hr})$ and for $\mathrm{P}$ absorption ranged from 1.10 to $1.16(\mathrm{~mol} / \mathrm{hr})$.

There was no significant interaction effect with feeding on DDGS with or without SW on Ca and P absorption. As shown in Table (4), the mean values for $\mathrm{Ca}$ absorption ranged from 2.57 to 2.94 (mol/hr) and for $\mathrm{P}$ absorption were ranged from 1.06 to $1.25(\mathrm{~mol} / \mathrm{hr}$ ) with feeding on the experimental rations.

Carbohydrates increased intestinal $\mathrm{Ca}^{2+}$ absorption as reported by (Buzinaro et al., 2006). Data regarding protein intake and intestinal $\mathrm{Ca}^{2+}$ absorption indicate that dietary protein does not alter the intestinal $\mathrm{Ca}^{2+}$ absorption and hence intestinal calcium absorption does not explain hypercalciuria induced by high protein intake (Kerstetter et al., 2003). However, the data related to the effect of dietary lipids on intestinal $\mathrm{Ca}^{2+}$ absorption are not clear (Buzinaro et al., 2006). In addition, a high phosphorus intake has been showed to cause hypocalcemia, hyperphosphatemia, secondary hyperparathyroidism with enhanced bone resorption and bone loss in several animal models (Calvo and Park, 1996).

Table 4. Interaction effects between feeding on DDGS with or without SW on $\mathrm{Ca}(\mathrm{mol} / \mathrm{hr})$ and $\mathrm{P}(\mathrm{mol} / \mathrm{hr})$ absorption at 13 weeks of age.

\begin{tabular}{|c|c|c|c|c|c|c|c|c|c|c|c|}
\hline Items & R1 & R2 & R3 & R4 & R5 & R6 & R7 & R8 & R9 & \multirow{3}{*}{$\begin{array}{c} \pm \\
\text { SEM }\end{array}$} & \multirow{3}{*}{$P$} \\
\hline DDGS(\%) & 0.0 & 10.0 & 20.0 & 0.0 & 10.0 & 20.0 & 0.0 & 10.0 & 20.0 & & \\
\hline SW(\%) & & 0.0 & & & 0.5 & & & 1.0 & & & \\
\hline $\mathrm{Ca}(\mathrm{mol} / \mathrm{hr})$ & 2.75 & 2.67 & 2.71 & 2.65 & 2.57 & 2.74 & 2.75 & 2.94 & 2.60 & 0.216 & 0.803 \\
\hline $\mathbf{P}(\mathrm{mol} / \mathrm{hr})$ & 1.06 & 1.14 & 1.16 & 1.25 & 1.06 & 1.15 & 1.16 & 1.12 & 1.09 & 0.103 & 0.718 \\
\hline
\end{tabular}

Phosphorus balance involves the absorption of dietary phosphorus in the intestine, its distribution in body fluids and tissues, especially bone and its excretion was largely by the kidney (Tani et al., 2007). Intestinal net phosphorus absorption was significantly increased by the high phosphorus diets, dependent on the amount of dietary phosphorus.

Effect of SW supplementation or feeding DDGS and their interaction on $C a$ and $P$ concentration $(\mathrm{mg} / 100 \mathrm{ml})$ in blood plasma:

As shown in Table 5, calcium concentration was increased $(\mathrm{P}<0.05)$ with supplemented $1 \% \mathrm{SW}(9.42 \mathrm{mg} / 100 \mathrm{ml})$ than supplemented 0.0 or $0.5 \%$ SW (5.16 and $7.86 \mathrm{mg} / 100 \mathrm{ml}$, respectively), while Ca concentration was higher $(\mathrm{P}<0.05)$ when supplemented $0.5 \% \mathrm{SW}$ than the control at 11 weeks of age. 
Table 5. Main effects SW supplementation or feeding DDGS on Ca and $P$ concentration $(\mathrm{mg} / 100 \mathrm{ml})$ in blood plasma from 7 to 13 weeks of age.

\begin{tabular}{|c|c|c|c|c|c|c|c|c|c|c|}
\hline \multirow{2}{*}{ Items } & \multicolumn{5}{|c|}{ SW(\%) } & \multicolumn{5}{|c|}{ DDGS(\%) } \\
\hline & 0.0 & 0.5 & 1.0 & \pm SEM & $P$ & 0.0 & 10.0 & 20.0 & \pm SEM & $P$ \\
\hline \multicolumn{11}{|c|}{ Ca concentration } \\
\hline WK (7) & 3.90 & 3.99 & 3.86 & 0.191 & 0.885 & 3.92 & 4.02 & 3.81 & 0.191 & 0.736 \\
\hline WK (9) & 4.47 & 4.39 & 3.86 & 0.262 & 0.229 & 4.05 & 4.34 & 4.33 & 0.262 & 0.676 \\
\hline WK (11) & $5.16^{c}$ & $7.86^{b}$ & $9.42^{\mathrm{a}}$ & 0.372 & $<.0001$ & $6.19^{b}$ & $7.20^{\mathrm{b}}$ & $9.04^{\mathrm{a}}$ & 0.372 & 0.0001 \\
\hline WK (13) & 9.66 & 9.19 & 9.35 & 0.576 & 0.841 & 9.46 & 9.40 & 9.33 & 0.576 & 0.987 \\
\hline Mean & $5.80^{b}$ & $6.36^{a}$ & $6.62^{a}$ & 0.184 & 0.016 & $5.91^{b}$ & $6.24^{\text {ab }}$ & $6.63^{a}$ & 0.184 & 0.042 \\
\hline \multicolumn{11}{|c|}{ P concentration } \\
\hline WK (7) & 1.52 & 1.29 & 1.45 & 0.509 & 0.950 & 1.43 & 1.37 & 1.46 & 0.509 & 0.992 \\
\hline WK (9) & $2.12^{\mathrm{b}}$ & $2.36^{b}$ & $4.97^{\mathrm{a}}$ & 0.498 & 0.001 & 3.04 & 2.82 & 3.59 & 0.498 & 0.543 \\
\hline WK (11) & 5.51 & 3.71 & 4.37 & 0.507 & 0.064 & 4.32 & 4.31 & 4.95 & 0.507 & 0.600 \\
\hline WK (13) & 6.52 & 6.87 & 7.08 & 0.424 & 0.647 & 6.85 & 7.48 & 6.13 & 0.424 & 0.109 \\
\hline Mean & $3.92^{\mathrm{ab}}$ & $3.56^{b}$ & $4.47^{a}$ & 0.227 & 0.034 & 3.91 & 4.00 & 4.03 & 0.227 & 0.928 \\
\hline
\end{tabular}

a, b, c : Means within the same raw with different superscripts are significantly different $(\mathrm{P}<0.05)$.

$\mathrm{SEM}=$ Standard error of means, $\quad P=$ Probability, $\quad \mathrm{Wk}=$ Week

The mean values, showed that supplemented $1 \%$ was higher $(\mathrm{P}<0.05)$ with supplemented $0.5 \%$ or $1 \% \mathrm{SW}(6.36$ and $6.62 \mathrm{mg} / 100 \mathrm{ml}$, respectively) than the control group $(5.80 \mathrm{mg} / 100 \mathrm{ml})$.

Phosphorous concentration increased $(\mathrm{P}<0.05)$ at 9 week with supplemented $1 \% \mathrm{SW}(4.97 \mathrm{mg} / 100 \mathrm{ml})$ than the control $(2.12 \mathrm{mg} / 100 \mathrm{ml})$ or supplemented $0.5 \% \mathrm{SW}(2.36 \mathrm{mg} / 100 \mathrm{ml})$. The mean values showed that the $\mathrm{P}$ concentration was higher $(\mathrm{P}<0.05)$ with supplemented $1 \% \mathrm{SW}(4.47 \mathrm{mg} / 100 \mathrm{ml})$ than with feeding on $0.5 \% \mathrm{SW}(3.56 \mathrm{mg} / 100 \mathrm{ml})$, while there was no significant effect between control $(3.92 \mathrm{mg} / 100 \mathrm{ml})$ and supplemented $0.5 \%$ or $1 \% \mathrm{SW}$.

Feeding on $20 \%$ DDGS increased $(\mathrm{P}<0.05)$ Ca concentration $(9.04$ $\mathrm{mg} / 100 \mathrm{ml})$ than the control $(9.16 \mathrm{mg} / 100 \mathrm{ml})$ or feeding on $10 \%$ DDGS $(7.20$ $\mathrm{mg} / 100 \mathrm{ml}$ ). There was no significant effect on P concentration with feeding on the control or $10 \%$ or $20 \%$ DDGS (3.91, 4.0 and $4.03 \mathrm{mg} / 100 \mathrm{ml}$, respectively).

As shown in Table 6, there was no significant interaction effect on the mean values for $\mathrm{Ca}$ and $\mathrm{P}$ concentration in blood plasma. Feeding on R6, R7, R8 and R9 increased Ca concentration $(6.87,6.39,6.50$ and $6.98 \mathrm{mg} / 100 \mathrm{ml}$, respectively) than the other rations, while feeding on R1, R8 and R9 increased $\mathrm{P}$ concentration $(4.29,4.26$ and $5.16 \mathrm{mg} / 100 \mathrm{ml}$, respectively) than the other rations. 
Table 6. Interaction effects between feeding on DDGS and with or without SW on Ca and $P$ concentration $(\mathrm{mg} / 100 \mathrm{ml})$ in blood plasma from 7 to 13 weeks of age.

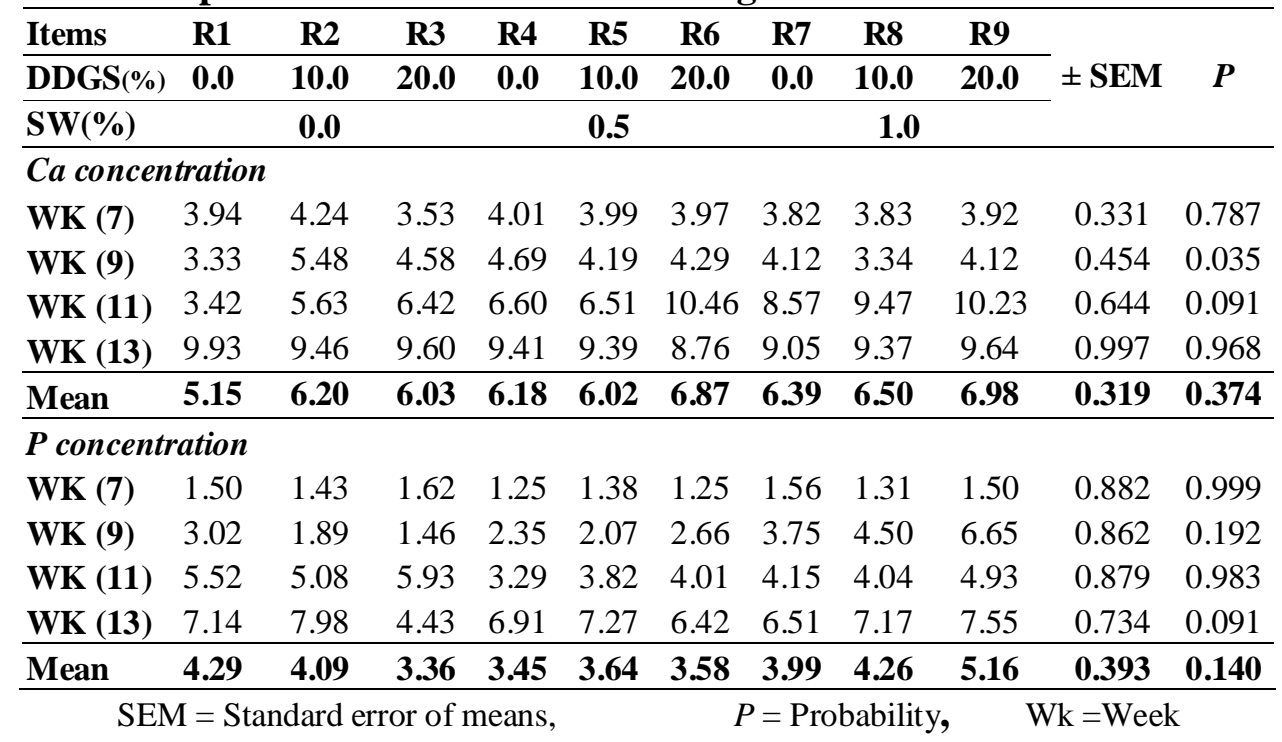

Calcium and phosphorous concentrations in blood were within the normal range as found by (Nichols, 2003). Because rabbits can absorb Ca without the facilitation of vitamin $\mathrm{D}$, a mechanism is needed to regulate serum Ca levels. Parathyroid hormone and calcitonin are thought prevent serum $\mathrm{Ca}$ level from becoming to dangerously high due to dietary influence (Cheeke, 1994). It is also thought that great majority of calcium absorbed by the gastrointestinal tract leaves the body through the urinary tract (Rosenthal, 2006).

Phosphorous (P) is an essential element of both plant and animals (Schindler, 1977). Therefore, in diets with higher energy contents, it may be necessary to raise the concentration of $\mathrm{P}$. Ultimately, $\mathrm{P}$ requirements for market animals should probably be based on the amount of $\mathrm{P}$ required per pound of lean tissue growth. A limiting factor in the use of digestible $\mathrm{P}$ in diet formulations is accuracy of P bioavailability estimates for feedstuffs (Robbins et al., 2000).

\section{Effect of SW supplementation or feeding DDGS and their interaction on some blood plasma parameters:}

As shown in Table 7, there was no significant effect on total protein concentration with supplemented SW or feeding DDGS. Supplemented SW at 1.0 $\%$ increased $(\mathrm{P}<0.05)$ albumin concentration $(4.47 \mathrm{~g} / 100 \mathrm{ml})$ than the control 
$(3.84 \mathrm{~g} / 100 \mathrm{ml})$, while there was no significant effect between supplemented $0.5 \%$ SW $(4.0 \mathrm{~g} / 100 \mathrm{ml})$ and the control or supplemented $1 \% \mathrm{SW}$. The AST activity was higher $(\mathrm{P}<0.05)$ with supplemented $0.5 \% \mathrm{SW}(51.11 \mathrm{U} / \mathrm{ml})$ than the control $(34.93 \mathrm{U} / \mathrm{ml})$ or $1 \% \mathrm{SW}(37.24 \mathrm{U} / \mathrm{ml})$, while feeding on $10 \%$ or $20 \%$ DDGS caused increasing $(\mathrm{P}<0.05)$ AST activity $(46.04$ and $46.84 \mathrm{U} / \mathrm{ml}$, respectively) than the control $(30.40 \mathrm{U} / \mathrm{ml})$. Alkaline phosphates (ALP) was higher $(\mathrm{P}<0.05)$ with supplemented $1 \% \mathrm{SW}(75.26 \mathrm{U} / 100 \mathrm{ml})$ than the control $(53.48 \mathrm{U} / 100 \mathrm{ml})$, while there was no significant effect between supplemented $0.5 \%$ SW $(65.12$ $\mathrm{U} / 100 \mathrm{ml}$ ) and control or supplemented $1 \% \mathrm{SW}$. Creatinine concentration increased $(\mathrm{P}<0.05)$ with supplemented $0.5 \%$ and $1 \%$ SW (1.09 and 1.20 $\mathrm{mg} / 100 \mathrm{ml}$, respectively) than the control $(0.95 \mathrm{mg} / 100 \mathrm{ml})$ or with feeding on 20 $\%$ DDGS $(1.14 \mathrm{mg} / 100 \mathrm{ml})$ than feeding on $0.0 \%$ and $10 \%$ DDGS $(1.05$ $\mathrm{mg} / 100 \mathrm{ml}$ for each one).

The interaction results in Table 8 show that urea-N concentration was increased $(\mathrm{P}<0.05)$ with feeding on $\mathrm{R} 2, \mathrm{R} 3$ and $\mathrm{R} 7$ (45.95, 45.37 and 46.53 $\mathrm{mg} / 100 \mathrm{ml}$, respectively) than the other rations. The present data were within the range as found by Igwebuike et al. (2008) and EL-Banna et al. (2005) except for globulin concentration with feeding on R1, R3, R5, R6, R7 and R8 which were lower than the normal range $(2.15-3.15 \mathrm{~g} / 100 \mathrm{~m})$. EL-Banna et al. (2005) found that the total protein level in plasma of rabbits consumed seaweed was slightly lower than that in the control group and in the meantime higher levels in AST and ALT enzymes in the treated groups. This could be due to increase of protein utilization and amino acids transamination in the treated groups.

Zinc and copper accumulate mostly in the liver tissue (Saito, 1996). However, there are other studies, which suggest that zinc and copper loading may lead to intoxication and increase liver enzymes levels (Saito, 1996 and Levengood et al., 2000) which may support the increase of AST and ALT. Serum alkaline phosphates (ALP) levels may increase in congestive heart failure as a result of injury to the liver (Harper et al., 1977). Changes in the dietary calcium level have been shown to have a profound influence on bone composition, parathyroid size and bone and plasma alkaline phosphates. Increasing enzyme levels in blood plasma resulting from a dietary calcium deficiency (Hurwitz and Griminger, 1973).

Feeding on R9 was higher $(\mathrm{P}<0.05)$ in cholesterol concentration $(224.68$ $\mathrm{mg} / 100 \mathrm{ml}$ ) than the other rations, while feeding on R3, R5 and R6 were higher ( $\mathrm{P}<0.05$ ) (202.22, 213.84 and $215.39 \mathrm{mg} / 100 \mathrm{ml}$, respectively) than the others. Triglycerides concentration was higher $(\mathrm{P}<0.05)$ with feeding on R3, R5, R6, R8 and R9 $(107.26,122.02,115.62,119.56$ and $133.58 \mathrm{mg} / 100 \mathrm{ml}$, respectively) than the other rations, and total lipids was also higher with the same relations (430.0, 
$225.0,267.5,232.5$ and $282.5 \mathrm{mg} / 100 \mathrm{ml}$, respectively). Low density lipoproteins (LDL) concentration was higher $(\mathrm{P}<0.05)$ with feeding on $\mathrm{R} 9(164.23$ $\mathrm{mg} / 100 \mathrm{ml}$ ) than the other rations, while feeding on R5, R6 and R7 were higher ( $\mathrm{P}$ $<0.05)(157.38,159.32$ and $155.34 \mathrm{mg} / 100 \mathrm{ml}$, respectively) than the others. There was no significant effect on high density lipoproteins (HDL) concentration and on the $\mathrm{pH}$ values with feeding on the experimental rations.

Blood Plasma cholesterol concentration is known to be influenced by the quantity and quality of fat in the diet. Low density lipoproteins (LDL) and cholesterol concentrations fall when saturated triglycerides in the diet is replaced by polyunsaturated vegetable oil (Spady and Woollett, 1990). Triglyceride (TG) is transported in blood via macromolecular particles called lipoproteins (Kleppe et al., 1988).

It has been concern that a substantial increase in carbohydrate containing food at the expense of fat, might result in a decreased in high-density lipoprotein and a corresponding increase in very low-density lipoprotein and triglycerides in the blood (Hicks et al., 1990).

Conclusively, agro-industrial by -products such as DDGS without supplemented seaweed could be increased urea-N in blood. Feeding on Distiller's dried grains with soluble led to increase the low density lipoprotein, triglycerides, cholesterol and total lipids in blood plasma of growing rabbits.

\section{REFERENCES}

Allain, C. C., Poon, L. S., Chan, C. S., Richmond W. and Fu, P. C. (1974). Enzymatic determination of total serum cholesterol. Clin. Chem., 20: 470.

Buzinaro, E. F., Almedia, R. N. and Mazets, G. M. (2006). Bioavailability of dietary calcium. Arq. Bras Endocrinol Metabol., 50: 852.

Calvo, M. S. and Park, Y. K. (1996). Changing phosphorus content of the U. S. diet: Potential for adverse effects on bone. J. Nutr., 126: 1168S.

Cheeke, P. R. (1994). Nutrition And Nutritional Diseases. In: Manning, P. J. , Ringler, D. H. and Newcomer C. E. (ed.). The Biology of the Laboratory rabbit. $2^{\text {nd }}$ ed. p. 321. Academic Press, New York.

Corl, B. A., Barbano, D. M., Bauman, D. E. and IP, C. (2003). Cis-9, trans-11 CLA derived endogenously from trans-11 18:1 reduces cancer risk in rats. Journal of Nutr., 133: 2893. 
Doumas, B. T., Carter, D. D., Peters, R. J., and Schaffer, T. R., (1981). A candidate reference method for determination of total protein in serum. Development and Validation. Clin. Chem., 27: 1642.

Duncan, D. B. (1955). Multiple Range and Multiple F Test. Biometrics, 11: 10.

El-Banna, S.G., Hassan, A. A., Okab, A. B., Koriem, A. A. and Ayoub, M. A. (2005). Effect of feeding diets supplemented with seaweed on growth performance and some blood hematological and biochemical characteristics of male baladi rabbits. The $4^{\text {th }}$ Inter. Con. on Rabbit Prod. in Hot Clim., Sharm El-Sheikh, Egypt, 373-382.

Fabiny D.L. and Ertingshausen G (1971). Automated reaction-rate method for determination of serum creatinine. Clin. Chem., 17: 696.

Fossati, P. and Prencipe, L. (1982). Clin. Chem., 28: 2077.

Fossati P, Prencipe L. and Berti G. (1980). Use of 3, 5-dichloro-2hydroxybenzenesulfonic acid/4-aminophenazone chromogenic system in direct enzyme assay of uric acid in serum and urine. Clin. Chem., 26: 227.

Freidman, R. B., Anderson, R. E., Entire, S. M. and Hinshberg, S. B. (1980). Clin. Chem., 26.

Friedewald, W. T., Levy, R. I., and Fredrickson, D.S. (1972). Estimation of the concentration of low-density lipoprotein cholesterol in plasma, without use of the preparative ultracentrifuge. Clin. Chem.,18: 499.

Harper, H. A., Rodwell, V. B.W. and Mayes, P. A. (1977). Review of Physiological Chemistry, $16^{\text {th }}$ ed., Lange Medical Publications, Los Altos, California, 94022.

Hicks, R. B., Owens, F. N., Gill, D. R., Martin, J. J. and Strasia, C. A. (1990). Effects of controlled feed intake on performance and carcass characteristics of feedlot steers and heifers. J. Anim. Sci., 68: 233.

Hill, P. G. and Wells, T. N. (1983). Ann. Clin Biochem., 20: 265.

Hurwitz, S. and Griminger, P. (1973). The response of plasma alkaline phosphatase, parathyroids and blood and bone minerals to calcium intake in the fowl. Journal of Nutr., U. S. A., 177 pp.

Igwebuike, J. U., Anugwe, F. O. I., Raji, A. O., Ehiobu, N. G. and Ikurior, S. A. (2008). Nutrient digestibility, haematological and serum biochemical indices of rabbits fed graded levels of Acacia Albida Pods. ARPN. Journal of Agricultural and Biological Science, 3 ( 4) : 33 .

Kerstetter, J. E., O’ Brien, K. O. and Insogna, K. L. (2003). Dietary protein, Calcium metabolism and skeletal homesotasis revisited. Am. J. Clin. Nutr., 78: S584. 
Kleppe, B. B., Aiello, R. J., Grummer, R. R. and Armentano, L. E. (1988). Triglycerides accumulation and very low density lipoprotein secretion by rat and goat hepatocytes in vitro. J. Dairy. Sci., 71: 1813.

Levengood, G. M., Sanderson, G. C., Anderson, W. L., Foley, G. L., Brown, P. W. and Seets, J. M. (2000). Influence of diet on the hematology and serum biochemistry of zinc-intoxicated mallards. Journal of Wildlife Disease, 36: 111.

Lebas, F., Coudert, P., de Rochambeau, H. and Thébault R.G. (1997). The Rabbit - Husbandry, Health and Production. FAO Animal Production and Health Series No. 21, FAO, Rome.

Lopes-Virella, M. F., Stone, P., Ellis, S. and Colwell, J. A. (1977). Cholesterol determination in high density lipoproteins separated by three different methods. Clin Chem., 23: 882.

Moorhead, W. R. and Briggs, H. C. (1974). 2-Amino-2-methyl-1-propanol as the Alkalizing Agent in an improved continuous-Flow cresolphthalein complexone procedure for calcium in serum. Clin Chem., 20: 1458.

Moughan, P. J., Schultze, W. H. and Smith, W. C. (1988). Amino acid requirements of the growing meat rabbit whole body tissue - a theoretical estimate of ideal amino acid balance. Animal Production, 47: 297.

Nichols, J. B. (2003). Rabbits. University Veterinarian, Florida Atlantic University, USA.

Reitman, A. and Frankel S. (1957). A colourimetric method of determination of SGOT and SGPT. American J. of Clinical Pathology, 28: 56.

Robbins, B. C., Radcliffe, J. S. and Kornegay, E. T. (2000). Evolution of two commercially available phytase sources in weanling pigs fed a high phytate diet. Journal of Animal Science, 78 (Suppl. 2): 5. (Abstract).

Rosenthal, K. L. (2006). Calcium Metabolism In Rabbits: What's New? The North American Veterinary Conference.

Robbins, B. C., Radcliffe, J. S. and Kornegay, E. T. (2000). Evolution of two commercially available phytase sources in weanling pigs fed a high phytate diet. Journal of Animal Science, 78 (Suppl. 2): 5, (Abstract).

Roy, A. V. (1970). Rapid method for determining alkaline phosphatase activity in serum with thymolphthalein monophosphate. Clin. Chem., 16(5): 431.

Saito, S. (1996). The effect of copper on zinc in liver and metallothionein. Res. Commun. Mol. Pathol. Pharmacol., 94: 259.

Santoma, G., de Blas, J. C., Carabano, R. and Fraga, M. J. (1989). Nutrition of Rabbits. In Haresign, W. and Cole, D. J. A. (eds) . Recent Advances in Animal Nutrition. Butter Worths, London, pp. 109. 
SAS (2000). Statistical Analysis System / STAT user's Guide, release 6.03. Ed., SAS Institute Inc., Cary, Nc. USA, PP. 125.

Schindler, D. W. (1977). Evolution of phosphorus limitation in Lakes. Sciences, 195: 260.

Scott, C. (1990). Kelp Help : Livestock thrive on seaweed. ELphin, Lanark Country, Easter Ontario, Canada.

Sinha, K. P., Prasad, R. L. and Adil, A. (2008). Blood Biochemical Profile in relation to Carbohydrate and Lipid metabolism in Rabbit. Veterinary World, 1 (1): 21

Soares, J. H. and Jr., (1995). Calcium Bioavailability. In: C. B. Ammerman, D. H. Baker and A. J. Lewis (ed.) Bioavailability of nutrients for Animals. P. 95. Academic Press, Inc., San Diego, CA.

Spady, D. K. and Woollett, L. A. (1990). Interaction of dietary saturated and polyunsaturated triglycerides in regulating the processes that determine plasma low density lipoprotein concentrations in the rat. Journal of lipid Research, 31: 1809.

Spiehs, M. J., Whitney, M. H. and Shurson, G. C. (2002). Nutrient database for distiller's dried grains with solubles produced from new ethanol plants in Minnesota and South Dakota. Journal of Anim. Sci., 80: 2639.

Tani, Y., Sato, T., Yamanaka-Okumura, H., Yamamoto, H.,Arai, H., Sawada, N., Genjida, K., Taketani, Y. and Takeda, E. (2007). Effects of prolonged high phosphorus diet on phosphorus and calcium balance in rats. Journal of Clin. Biochem. Nutr., 40: 221.

Whitney, M. H., Spiehs, M. J. and Shurson, G. C. (1999). Use of Minnesota South Dakota Regional Distiller's dried grain with soluble in swine diets. $60^{\text {th }}$ Minnesota Nutrition Conference $\alpha$ Zinpro Technical Symposium, Bloomington, M. N. P. 171.

Zollner, N. and Kirsch K. (1962). A Colorimetric Method To Determine Total Lipid.Z. Ges, Exp. Med., 135. 


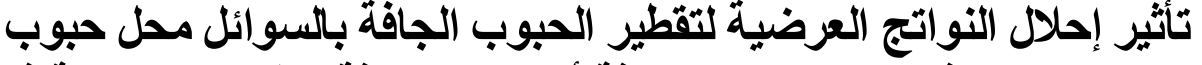

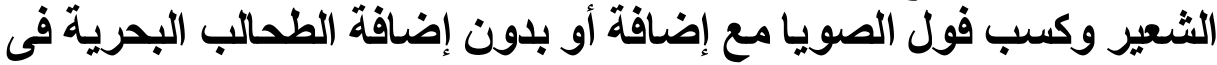

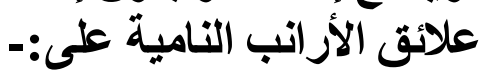
r ـ المأكول وامتصاص الكالسيوم والفسفور وبعض مكونات الام فى الأرانب النامية.

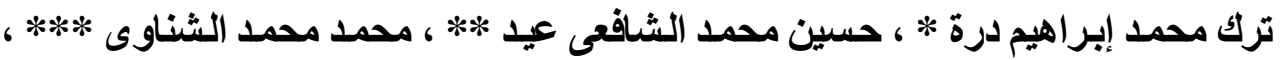

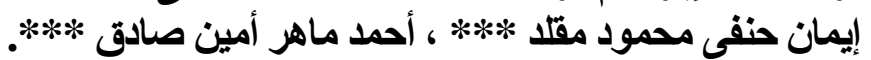

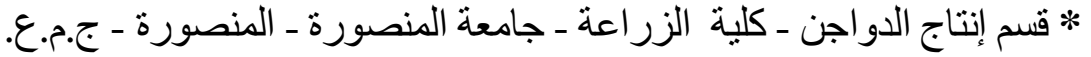

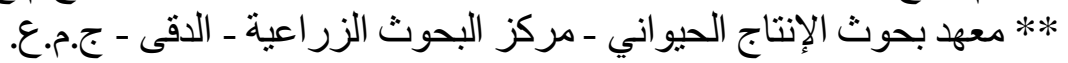

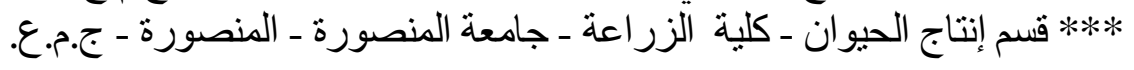

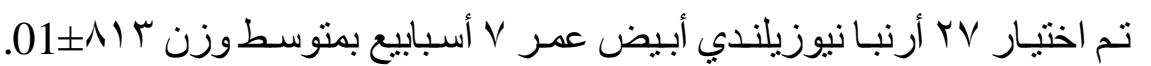

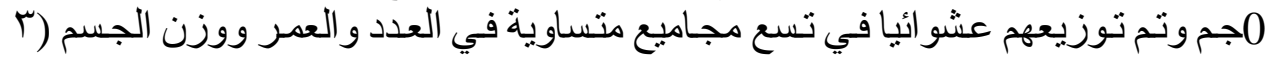

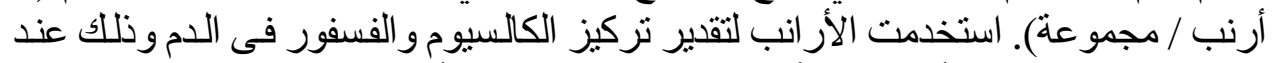

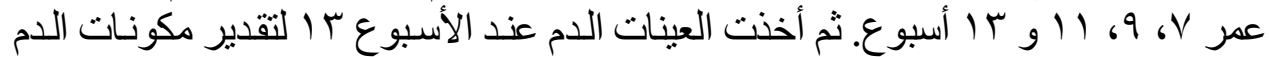

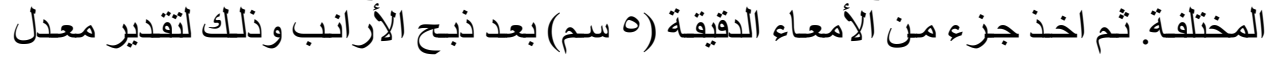
امتصاص كل من الكالسيوم و الفسفور الاء.

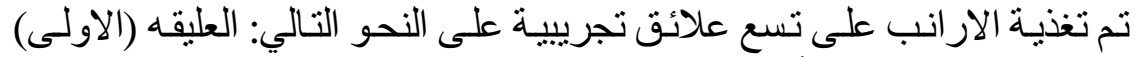

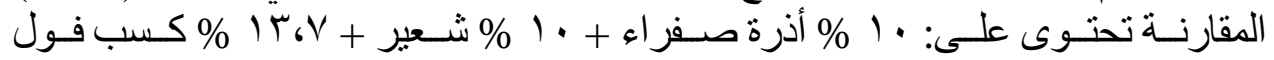

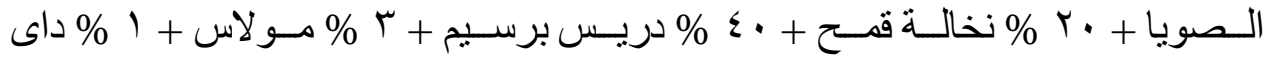

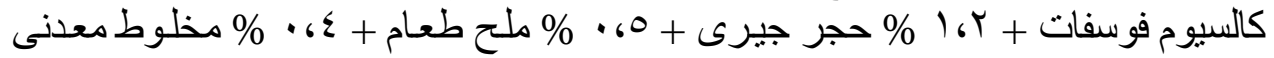

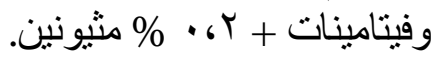

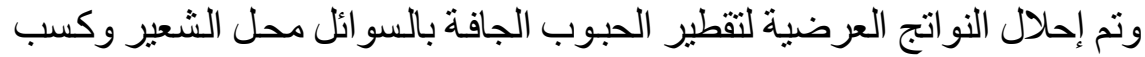

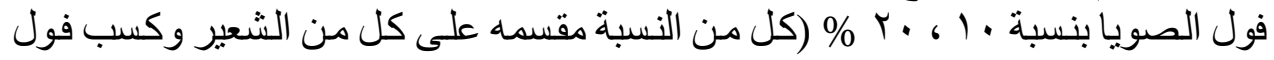

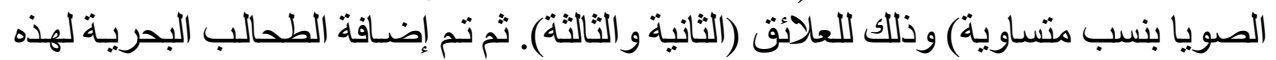
العلائق بنسبة 0، • \% وذللك لكل من العليقة الر ابعـة والخامسة و السادسة. كمـا تم إضـافة

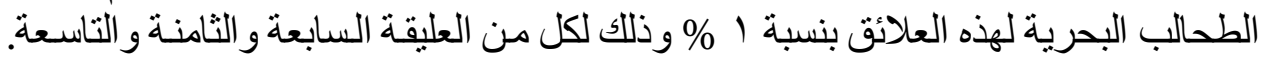

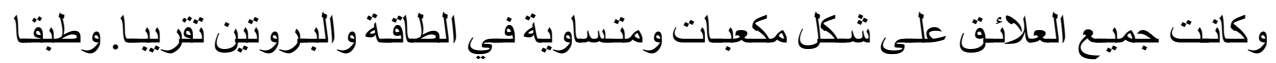
للاحتياجات المطلوبة لتغذية الأر انب النب النامية.

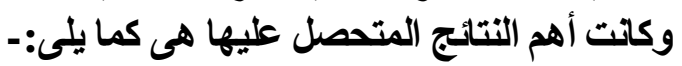

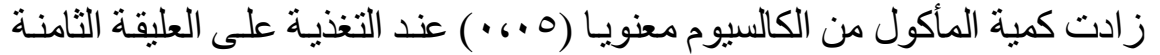

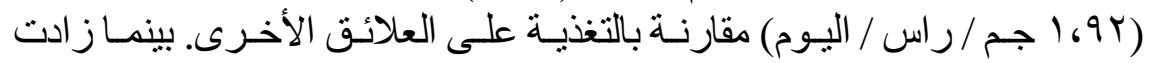




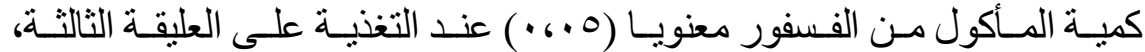

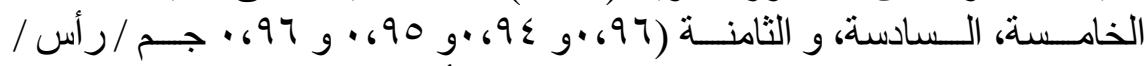
اليوم، على التو الى) مقارنة بالتغذية على العلائق الأخرى.

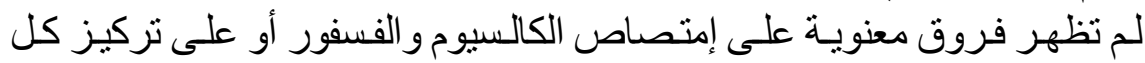
منها فى الدم نتيجة للمعاملات التجريبية المختلفة.

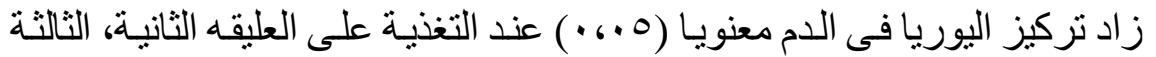

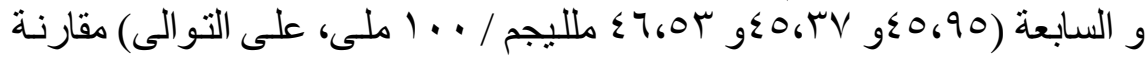
بالتغذية على العلائق التجريبية الأخرى.

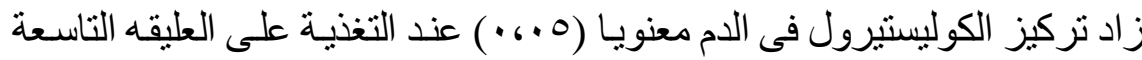

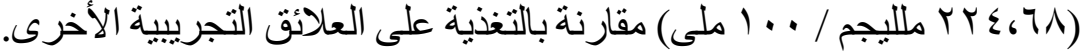

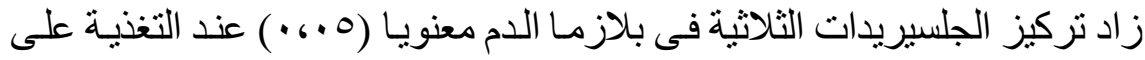

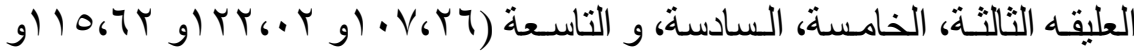

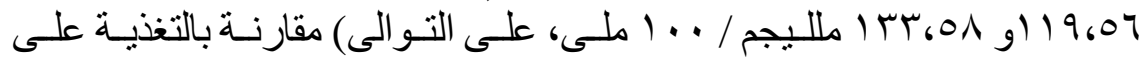

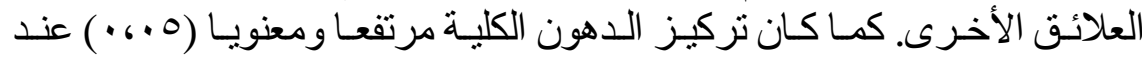

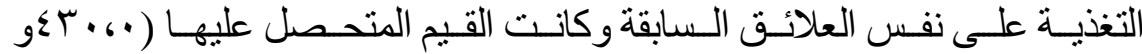

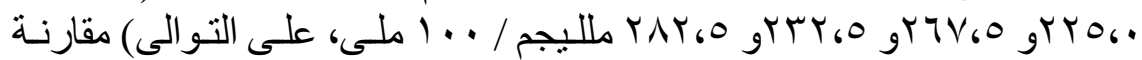
بالتغذية على العلائق التجريبية الأخرى.

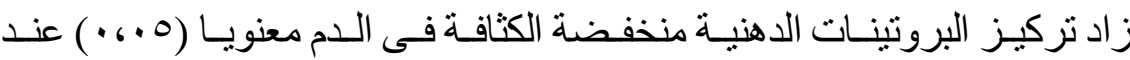

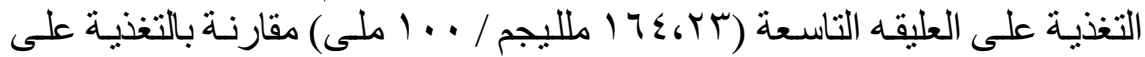

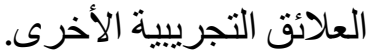

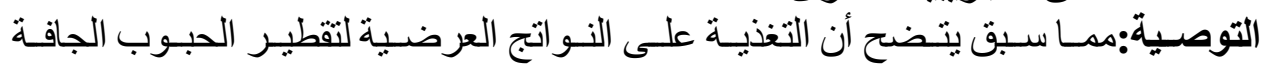

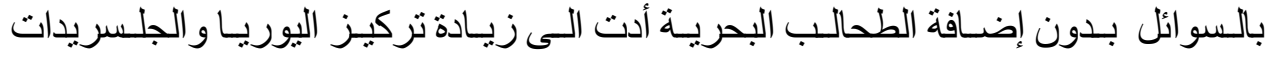

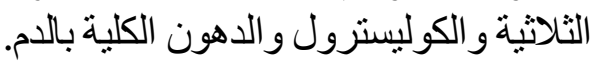

